\title{
KEWIRASWASTAAN sebagai sebuah alterantif
}

Oleh : M. Akhyar Adnan

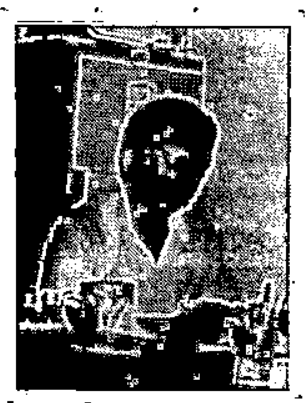

Drs. Muhammad Akhyar Adnan, Ak. adalah alumnus Fakultas Ekonomi Universitas Gadjah Mada Yogyakarta. dilahirkan di Pekanbaru, 13 Junl 1958. Sejak April 1986 memulal profesi sebagai Staf Edukatlf di Fakultas Ekonomi Universitas Islam Indonesia. Sebelumnya, pernah bekerja di PT (Persero) Pembangunan Perumahan Jakarta dan Surabaya. Semasa mahasiswa pernah menjabat sebagai Ketua Badan Pemeriksa Koperasi Mahasiswa (KOPMA) UGM periode 1981 - 1982 dan periode 1982 - 1983, di samping pernah melakukan auditing dan ikut dalam penyusunan System Akuntansi di beberapa perusahaan besar di Yogyakarta, Surabaya dan Ujung Pandang dalam fungsinya sebagai Asisten pada Kantor Akuntan Publik Dr. Moechtar Talib.

\section{Pendahuluan}

Berbicara masalah kewiraswastaan adakalanya kita rasakan bagaikan berbicara tentang seekor kucing yang berada dalam karung. Artinya, secara sepintas dan global kita tahu apa dan bagaimana seekor kucing, tetapi bagaimana kondisi yang sebenarnya sang kucing yang berada dalam karung tersebut, seperti apa warnanya, bagaimana bulunya, apakah sehat atau sakit, dsb. dsb., kita tidak tahu secara pasti. Demikian pula dengan Kewiraswastaan mungkin hampir semua orang merasa sudah tahu apa itu kewiraswastaan, karena sering mendengar atau membacanya, tetapi bila ditanyakan betul lebih jauh, maka cenderung timbul banyak persepsi yang berbeda-beda antara satu sama lain.

Sekedar contoh, bila kita bertanya pada seseorang, "Saudara bekerja dimana?", maka mungkin dia menjawab, : "Oh, saya tidak bekerja dimanamana, saya berwirasuasta!" Lantas kalau dikejar lebih jauh, : "dibidang apa Saudara berwiraswasta?", mungkin saja dia menjawab,: "saya punya kios rokok di ujung jalan sana".

Terhadap dialog diatas, mungkin masing-masing kita akan berbeda pendapat 
sebagian akan mengatakan, : "Wah, kalau hanya jual rokok sih, bukan wiraswasta namanya", tetapi sebagian yang lain, mungkin berpendapat bahwa membuka warung dan menjual rokok adalah juga wiraswasta.|

Perbedaan pendapat diatas tentunya merupakan bukti bahwa memang ada lebih dari satu persepsi tentang arti dan pengertian wirasuasta atau kewiraswastaan tersebut. Tidak hanya di kalangan orang awam, para ahli pun tampaknya belum mempunyai kesamaan persepsi tentang apa dan bagaimana wiraswasta atau kewiraswastaan|tersebut.

Misalnya saja Suhadi (1985, p.43), mengatakan leksikal wiraswasta bermakna berdiri diatas kemampuan sendiri, sedang secara terminologis wiraswasta|dikatakan mengandung makna suatu sifat keberanian, keutamaan keteladanan dalam mengambil resiko yang bersumber atas kemampuan sendiri.

Sementara itu. S. Hardjoseputro (1987, p.2) mengatakan bahwa wiraswasta adalah individu-individu yang berorientasi kepada tindakan-tindakan yang beresiko tinggi, serta berani dalam mengambil resiko dalam mencapai tujuannya, dan mempunyai ciri-ciri : percaya diri, berorientasi kepada tugas dan hasil, pengambil resiko, mempunyai kemampuan memimpin, orisinil dan berorientasi ke masa depan.

Dilain pihak, Soehardi Sigit (1980, p.2) sebagaimana juga banyak yang mengakui, mengatakan bahwa wiraswasta|atau wirausal .arasal dari kata entreprenuer dan kewiraswastaan. adalah entreprenuership. Bila ditelusuri lebih jauh, di Amerika Serikat sendiri, ternyata istilah entreprenuer belum mempunyai arti dan makna yang sama bagi setiap orang. Ada yang mengidentikkan dengan pengusaha kecil, ada pula yang mengartikannya sebagai perusahaan atau ada pula yang memformulasikannya sebagai orang yang memadukan berbagai unsur produksi, yang. menciptakan barang baru, yang berani mengambil resiko, dsb. dsb.

Berangkat dari persepsi masingmasing, para ahli pun mencoba menjabarkan profil seorang wiraswastawan| berdasarkan paham yang mereka anut makna yang mereka jadikan dasar pengertian kewiraswastaan b seperti contoh ciri yang diajukan oleh S. Hardjoseputro diatas.

Terlepas dari ketidaksamaan persepsi diantara banyak ahli yang sudah mencoba mengemukaḳan pendapatnya, ada satu hal yang patut dicatat, yakni, tidak satupun ahli yang beranggapan atau mengatakan bahwa wiraswasta ; atau kewiraswastaan ttu jelek, sehingga perlu dibuang jauh-jauh. Yang terjadi justru semuanya sepakat mengatakan bahwa sikap kewiraswastaan itu baik, sehingga perlu dipupuk dan dikembangkan. Malah ada yang berteori: untuk menjadi bangsa yang besar secara ekonomis, setidaknya $2 \%$ penduduk atau warga suatu bangsa akan berkembang secara ekonomis apabila bangsa itu mempunyai wiraswastawan-wiraswastawan! mempunyai kebebasan dan motif-motif yang mendorongnya untuk mengambil keputusan-keputusan yang bersifat kewiraswastaan| yang sebetulnya berarti mengadakan inovasi, yaitu mewujudkan gagasan-gagasan baru menjadi praktek. Dus, kesimpulannya, semua ahli sepakat berpendapat bahwa kewiraswastaan itu baik adanya dan patut dikembangkan. 
Bila dilihat pula penjabaran yang lebih jauh dari setiap persepsi para ahli tersebut, maka semuanya mengkaitkan sifat-sifat tertentu yang mutlak dimiliki untuk dapat menjadi seorang wiraswastawan, atau dengan kata lain, merupakan sifat-sifat yang melekat erat pada orang yang berwiraswasta atau orang yang ingin berwiraswasta seperti sifat percaya diri, kreatif, innovatif, kepemimpinan, berani menanggung resiko, berorientasi kepada masa depan, mampu menghasilkan sesuatu yang bermanfaat bagi dirinya dan bagi orang lain dsb, dsb.

\section{Sebagai Alternatif.}

Berdasarkan uraian diatas, tentunya dalam tulisan sederhana ini, kita tidak perlu berdebat soal baik-buruknya berwiraswasta tersebut, karena secara teoritis memang tidak ada jeleknya.

Dengan melihat peta ketenaga kerjaan di Indonesia dewasa ini dan terlebih lagi dengan membayangkan proyeksinya dimasa mendatang, justru kita melihat betapa sebetulnya kewiraswasthan merupakan suatu alternatif yang menarik untuk dikaji dan dicoba untuk dijalankan.

Tanpa melihat angka-angka pada tabel pun, dengan mudah kita bisa membayangkan betapa tidak seimbangnya atara demand dan supply tenaga kerja di Indonesia saat ini terlebih lagi dimasa mendatang. Kita bisa menghitung berapa besarnya output sekolahsekolah atau lembaga-lembaga pendidikan yang dihasilkan setiap tahunnya sebagai suplai atau penawaran lenaga kerja.

Jumlah itupun cenderung setiap tahun makin membengkak, dan itu belum lagi memperhitungkan supply tenaga kerja yang berasal dari menjadi dewasanya remaja yang tidak sempat mengenyam pendidikan yang umumnya berasal dari desa atau dari keluarga yang kurang mampu secara ekonomis, dilain pihak kita juga dapat membayangkan jumlah lembaga (perusahaan-perusahaan, instansi negeri atau swasta) yang membutuhkan tenaga kerja dan pertumbuhan jumlahnya setiap tahun, belum lagi akibat kemajuan zaman dan teknologi, dengan diciptakannya mesin-mesin canggih yang dapat menggantikan tenaga manusia dengan hasil yang lebih baik, kuantitas maupun kualitas, kesemuanya itu merupakan gambaran demand yang jelas-jelas tidak seimbang dengan besarnya supply.

Oleh karena itu, memang harus disiapkan suatu terobosan yang dapat mencegah terjadinya kondisi yang lebih buruk lagi. Kewiraswastaan, agaknya merupakan alternatif yang terbaik yang bisa dicoba, yang mudah-mudahan bisa pula berfungsi sebagai katup pengaman dari melimpah-ruahnya suplai tenaga kerja tersebut.

Membiarkan kondisi ini berjalan terus, tanpa berusaha mencarikan jalan keluar yang 'memadai, adalah suatu sikap naif yang mengundang terjadinya bahaya besar, baik dari segi ekonomi, sosial budaya dan bahkan dapat merembet kepada persoalan politik.

\section{Ukuran-ukuran kewiraswastaan}

Kalau kita sepakati bahwa wiraswasta atau kewiraswastaan adalah salah satu alternatif yang cukup penting dalam rangka mengantisipasi masalah ketidak seimbangan antara supply dan demand tenaga kerja, tentu-sebetulnya - harus 
kita sepakati lebih dulu apa dan bagaimana bentuk kewiraswastaan yang dimaksud.

Diatas diakui memang, bahwa masih simpang siurnya persepsi para ahli tentang pengertian dan terminologi wirasuasta atau kewiraswastaan tersebut. Keragaman persepsi tersebut pada gilirannya merancukan pula sifat atau karakteristik yang mestinya dimiliki seorang wiraswasta. Tanpa berpretensi untuk bertele-tele dalam pembicaraan persepsi atau pengertian dan karakteristik yang harus melekat pada wiraswastawan, penulis melihat bahwa, pertama, ternyata seluruh sifat atau karakteristik yang dijadikan tolok ukur oleh masingmasing ahli, kesemuanya adalah sifatsifat yang baik bahkan ideal, dilihat dari segi apapun, kedua, terdapat beberapa persamaan tolok ukur diantara sebagian ahli, ketiga, perbedaan yang ada dibanding esensinya, atau dengan kata lain, esensinya sama, hanya dalam mengurutkannya berbeda antara ahli yang satu dengan ahli yang lainnya. Oleh sebab itu, bisa saja seluruh karakteristik yang disyaratkan para ahli tersebut dijadikan tolok ukur, seperti :

- berani mengambil resiko

- imajinatif kreatif

- innovatif, yang innovasinya dapat diterima oleh umum

- mampu memotivasi orang lain

- percaya diri

- berorientasi ke masa depan

- berorientasi pada tugas dan hasil

- orisinalitas

- dapat mengendalikan diri

- memiliki kebutuhan untuk berprestasi, dsb, dsb.

\section{Problema}

Kalau dalil yang mengatakan bahwa "suatu bangsa yang ingin maju, setidaknya 2 prosen dari penduduknya haruslah merupakan wiraswastawan dalam arti yang sesungguhnya" dan "suatu bangsa akan maju secara ekonomis apabila bangsa tersebut mempunyai wiraswasta yang mempunyai kebebasan dan motif-motif yang kuat untuk berinovasi" benar adanya, maka dapat kita simpulkan bahwa jumlah wiraswastawan yang kita miliki masih dibawah angka minimal, disamping kualitasnya juga masih berada dibawah standar ideal. Kesimpulan ini ditarik atas dasar kenyataan bahwa yang besar secara ekonomis.

Maka oleh karena itu, yang harus menjadi perhatian utama kita saat ini adalah, bagaimana menambah jumlah wirasuasta yang berkualitas, atau dengan kata lain bagaimana melahirkan wiraswastawan-wiraswastawan yang sekarang sudah ada.

Dengan merujuk pada sikap dasar (karakteristik) yang harus dimiliki seorang wirasuastawan yang sesungguhnya, maka dalam rangka mencapai apa yang diharapkan diatas (menciptakan wirasuastawan tangguh), tentunya harapan harus ditujukan pada sektor pendidikan. Betul, bahwa sebagian sikap dasar yang harus dimiliki wiraswastawan yang ditulis diatas adalah seakan-akan sifatnya bawaan dari 'sono' nya, artinya tanpa pendidikan formalpun seseorang juga bisa menjadi wiraswastawan ulung yang memiliki sifat-sifat tersebut secara utuh, tetapi yang demikian itu tentu sangat sedikit sekali jumlahnya, atau jangan lupa bahwa terbentuknya mentalitas kewiraswastaan yang tanpa 
pendidikan formal itu justru sebagai akibat tempaan lingkungan atau pendidikan informal dari keluarganya, dus artinya masih terlibatnya unsur-unsur luar dalam pembentukan sifat atau mentalitas tersebut, walau mungkin secara tidak sengaja, nah dengan demikian, toh dapat dikatakan bahwa sebetulnya unsur pendidikan sebetulnya dapat berperan cukup berarti dalam meningkatkan jumlah maupun kualitas manusia yang bermental wiraswasta.

Tetapi persoalannya adalah pemikirpemikir dari kalangan pendidikan belum banyak - untuk tidak mengatakan tidak ada sama sekali - yang memikirkan alternatif ini secara serius, walau mungkin mereka sering berteriak dan mengeluh tentang tidak seimbangnya antara demand dan supply tenaga kerja.

Yang penulis maksud diatas adalah, belum tampaknya usaha yang serius yang mengarahkan pola pendidikan untuk menjadikan anak didik pada akhirnya mempunyai mental atau sikap wiraswasta yang sebenarnya, yakni memiliki sifat - sifat, yang menjadi ciri ' ' seorang wiraswasta yang sebenarnya seperti diungkapkan didepan. Justru yang terjadi adalah sebaliknya, output lembaga pendidikan cenderung memiliki sifat dan sikap yang menutup kemungkinan dirinya untuk menjadi seorang wiraswastawan dalam arti yang sebenarnyà. Misal saja, umumnya output lembaga pendidikan baik yang hanya dari pendidikan dasar, lanjutan, ataupun perguruan tinggi sekalipun - masih melihat 'menjadi pegawai negeri' sebagai pilihan utama, ini dapat kita buktikan dengan melihat betapa amat panjangnya antrian pengambilan formulir calon pegawai negeri, sampai-sampai malah pernah menimbulkan kekisruhan yang harus meminta korban, ingat kasus UGM tahun 1987 yang lalu.

Misal lain, masih terlalu amat sedikit output lembaga pendidikan kita yang secara sadar, berani mengambil resiko umpamanya dengan melakukan suatu kegiatan imajinatif-kreatif-invonatifproduktif yang dapat menghasilkan secara ekonomis. Yang terjadi justeru adanyanya kecenderungan untuk hanya menanti dan menanti kesempatan yang amat sangat langka dari lembaga yang sudah mapan, walau untuk itu mereka harus mengorbankan dana dan waktu yang tidak sedikit. Mereka cenderung bersikap feodal dan bermental priyayi dengan cara masih membedakan profesi yang white dan blue collar.

Masih banyak contoh lain yang menunjukkan betapa masih jauhnya jarak mentalitas outpun pendidikan yang kita miliki saat ini dibanding mentalitas yang seyogyanya dimiliki oleh wirasuastawan. Nah, kalau-sekali lagikita sepakati adagium yang mengatakan bahwakewiraswastaanakan mempunyai kontribusi yang amat besar terhadap maju dan besanya suatu bangsa, dan kewirasuastaan adalah sebuah terobosan yang pantas dilakukan, mau tidak mau, mestinya sejak sekarang kita berani melakukan perubahan pola pendidikan kita. Ataukah lembaga kita (FE UII) bisa memulainya ???,semoga saja.

\section{DAFTAR PUSTAKA}

Hardjoseputro S., Berjaya Karena Wiraswasta, Penerbit Galaxy Puspa Mega, Jakarta, 1987 
Suhadi, Wiraswasta Sampah, Suatu Alternatif Ekonomi Yang Perlu Dijajagi, Penerbit PT Bina limu, Surabaya, 1985

Soehardi Sigit, Drs., Mengembangkan Kewiraswastaan, Pendidikan Ahli Administrasi Perusahaan FE UGM, 1980.
Soehardi Sigit, Drs., Ekonomi Makro dan Kewiraswastaan, makalah Diskusi Panel di FE UII, 13 April 1988.

Yusuf Randy, Sukses Hanya Milik Orang 'Brutal', makalah Diskusi Panel di FE UII, 13 April 1988.

Yogya, $\frac{15 \text { Ramadhan } 1408 \mathrm{H}}{2 \mathrm{M} \text { e i } 1988 \mathrm{M} .}$ 